\title{
Influence of water having variable salinity and sodicity on groundnut- I : Effect on growth, yield attributes, yield and quality
}

R.D. Meghwal, J.V. Polara and M.A. Davara

Received : 20.05.2020; Revised : 06.11.2020; Accepted : 19.11 .2020

\author{
MEMBERS OF RESEARCH FORUM \\ Corresponding author : \\ J.V. Polara, Department of \\ Agricultural Chemistry and Soil \\ Science, Junagadh Agricultural \\ University, Junagadh (Gujarat) \\ India \\ Email: jvpolara@jau.in
}

Co-authors :

R.D. Meghwal and M.A. Davara, Department of Agricultural Chemistry and Soil Science, Junagadh Agricultural University, Junagadh (Gujarat) India

\section{Summary}

A pot experiment was conducted at Net House, Department of Agricultural Chemistry and Soil Science, Junagadh Agricultural University, Junagadh to assess four levels each of salinity $\left(2,4,6\right.$ and $\left.8 \mathrm{dS} \mathrm{m}^{-1}\right)$ and sodicity $(5.0,10.0,15.0$ and 20.0 SAR $)$ of irrigation water on groundnut by adopting factorial CRD with three replications. The results indicated that application of different levels of saline and sodic irrigation water produced significant effect on growth, yield attributes, yield and quality of groundnut crop. The maximum plant height, number of mature and immature pods plant ${ }^{-1}$, weight of mature and immature pods plant ${ }^{-1}$, days to $50 \%$ flowering, pod and haulm yield and harvest index were observed with EC $2 \mathrm{dS} \mathrm{m}^{-1}$ and SAR 5.0 and the lowest with EC $8 \mathrm{dS} \mathrm{m}^{-1}$ and SAR 20.0 of irrigation water. The quality parameters like seed index and protein content were found maximum with the saline irrigation water level of EC-2 dS m ${ }^{-1}$ and SAR-5.0, but there was no any pod formation recorded with EC-8 $\mathrm{dS} \mathrm{m}^{-1}$. The interaction effect between salinity and sodicity levels of irrigation water on pod $\left(8.10 \mathrm{~g} \mathrm{pot}^{-1}\right)$, kernel $\left(5.36 \mathrm{~g} \mathrm{pot}^{-1}\right)$ and biological $\left(26.61 \mathrm{~g} \mathrm{pot}^{-1}\right)$ yield were found significantly the highest with $\mathrm{C}_{1} \times \mathrm{S}_{1}$ (EC- $\left.2.0 \mathrm{dS} \mathrm{m}^{-1} \times \mathrm{SAR}-5.0\right)$ while no any pod formation were observed with $\mathrm{C}_{4} \times \mathrm{S}_{1}$, $\mathrm{C}_{4} \times \mathrm{S}_{2}, \mathrm{C}_{4} \times \mathrm{S}_{3}$ and $\mathrm{C}_{4} \times \mathrm{S}_{4}$ level of irrigation water.

Key words : Groundnut, Salinity, Sodicity, Growth, Yield and Yield attributes and Quality

How to cite this article :Meghwal, R. D., Polara, J. V. and Davara, M.A. (2020). Influence of water having variable salinity and sodicity on groundnut- I : Effect on growth, yield attributes, yield and quality. Asian J. Soil Sci., 15(2): 91-96 : DOI : 10.15740/HAS/AJSS/15.2/91-96. Copyright@2020: Hind Agri-Horticultural Society. 